\title{
Comparative study on dam site selection in the pre-feasibility stage of Shitouzhai Hydropower Station
}

\author{
Pan Shaohong* and Zhang Hongpin \\ Yunnan Land and Resources Vocational College, Yangzonghai Distrcit, Kunming, Yunnan Province, China.
}

\begin{abstract}
The selection of dam site is the key content in the early stage of hydropower station project. Based on the hydrology, topographic and geological conditions, kinetic energy economic indexes, flood loss of reservoir, project layout, electromechanical and metal structure, construction conditions and project investment of the proposed dam site, this paper makes an in-depth analysis of the dam site selection in the pre-feasibility stage of Shitouzhai Hydropower Station, in order to provide beneficial inspiration for the design of similar projects.
\end{abstract}

\section{Introduction}

The selection of dam site is the core link of hydropower project design $^{[1]}$. The reasonable selection of dam site is conducive to ensuring project safety, shortening construction period and reducing construction investment. Therefore, it is of great significance to compare and select dam site at the initial stage of engineering construction ${ }^{[2]}$. Based on the preliminary feasibility study stage ShiTouzhai hydropower Station dam site selection, for example, plans to choose from ShiTouzhai hydropower project dam site hydrology, topography and geological conditions, the kinetic energy of economic indicators, reservoir inundation loss, engineering layout, mechanical and electronic and metal structure, construction conditions and investment aspects of a comprehensive economic and technical comparison, the final selection of dam site recommend dam site for preliminary feasibility study stage.

\section{Project summary}

Shitouzhai Hydropower Station is located at $30.8 \mathrm{~km}$ of the highway road along the downstream of Liuku, Nujiang Prefecture, Yunnan Province, and $7 \mathrm{~km}$ downstream of Shangjiang Township, Nujiang Prefecture. It is the tenth stage of the 13-stage development plan of two reservoirs in the middle and lower nujiang River. The upstream of the hydropower station is Liuku hydropower station, and the downstream is Saige hydropower station. Shitouzhai Hydropower Station is about $31 \mathrm{~km}$ away from The highway of Liuku Town, where the nujiang prefecture is located, and $636 \mathrm{~km}$ away from the highway of Kunming city, with convenient transportation. The power station is a large (II) hydroelectric project with comprehensive benefits such as power generation, irrigation, water and soil

*Corresponding author: 201310135@yngtxy.edu.cn conservation and tourism. The main buildings are grade 2 , and the secondary buildings are grade 3 . The control basin area above the dam site is $111987 \mathrm{~km}^{2}$, with an average annual flow of $1590 \mathrm{~m}^{3} / \mathrm{s}$, an average annual runoff of 50.14 billion $\mathrm{m}^{3}$, a normal reservoir water level of $784 \mathrm{~m}$, a total storage capacity of $1.13 \times 10^{8} \mathrm{~m}^{3}$, a single reference flow of $622 \mathrm{~m}^{3} / \mathrm{s}$, and an installed capacity of $520 \mathrm{MW}$.

\section{The alternative dam site}

Shitouzhai Hydropower Station is about $35 \mathrm{~km}$ away from Liuku Hydropower Station in the upstream, and main submerged objects of the reservoir area are the settlements across the River from Liuku Town and Wanqiao Village, the farmland and villages along the river in Shangjiang Township, The New village of Baili and the secondary highway from Jinchangling to Liuku.. If the connection between the cascade power stations is considered, the Town of Liuku will be greatly submerged. The valley in the reach from Liuku to Shangjiang Township is winding and curved, with gentle slope, gully tributaries on both sides developed, and gully mouths are alluvial fans. There are cultivated land and residential areas on the gentle slope platform of diluvial fan, there is no suitable dam site location.

After investigation, the left bank of the upstream $4 \mathrm{~km}$ of the original planned dam site is the large tributary Sunzu River, and the right bank is the diluvial fan accumulation area of tributary Binggong River, with open terrain. On the right bank, $1 \mathrm{~km}$ downstream, there is a Bangwa river. The gully is piled up by diluvial fans and the terrain is open. The section of River from Bangwa Creek to Shuanghongqiao is a key area of hot zone development in Baoshan City, Yunnan Province.

The selection of the site of Shuanghongqiao will bring about great flood losses, difficulties in resettlement 
of immigrants, destruction of provincial cultural relics, reduction of the scale of Saige power station and other problems. Therefore, the location of the dam should be selected on the $4 \mathrm{~km}$ reach between Sunzu River and Bangwa River above the key area of hot zone development in Baoshan City. According to hydrological and topographical geological conditions, the upper dam site on the $1 \mathrm{~km} \sim 2 \mathrm{~km}$ reach of the lower reaches of Sunzu River, a tributary on the left bank, and the lower dam site on the $1 \mathrm{~km}$ reach of the upper reaches of Banwa River on the right bank were initially designed for comparison and selection. Because the upper and lower dam sites are close to each other and the river drop is small, the same normal water level is used to compare the dam site schemes in the pre-feasibility stage.

Concrete gravity dam is adopt according to the upper and lower dam site topography, general arrangement, construction diversion arrangement study in preliminary feasibility study stage. Five schemes of open channel diversion scheme, tunnel diversion scheme and staged diversion scheme of upper and lower dam site on the left bank of powerhouse, right bank of powerhouse and lower dam site on the right bank of powerhouse were developed to deepen the layout and study, and the technical and economic comparison was conducted, and the following conclusions were drawn.

\subsection{Comparison of hydrological and topographical conditions}

The upper and lower dam sites are about $3.0 \mathrm{~km}$ apart, and there are no large tributaries flowing into the upper and lower dam sites. The hydrological conditions are basically the same.

The topographic conditions and engineering geology of the upper and lower dam sites are compared in detail.

\subsubsection{Comparison of slope of topography on both sides}

On the left bank of the upper dam site, On the left bank of the dam site, the terrain is gentle below $773 \mathrm{~m}$ and the slope is $5^{\circ} \sim 15^{\circ}$. The topographic slope from above to near the normal water level line is $30^{\circ}$, with steep cliffs locally. The topographic gradient near the normal water level line on the right bank is $23^{\circ} \sim 32^{\circ}$, while the topographic gradient above is steeper, about $37^{\circ}$. The overall topographic slope of the left bank of the lower dam site is $35^{\circ} \sim 45^{\circ}$. The terrain below the normal water level line on the right bank is gentle, with a slope of $6^{\circ} \sim 20^{\circ}$, while the terrain above is slightly steep, with a slope of $33^{\circ} \sim 63^{\circ}$, with steep cliffs locally. Comparatively speaking, the right bank of the upper dam site has a gentle slope terrace, which is conducive to the arrangement of longitudinal cofferdams.

\subsubsection{Compare terrace and gentle slope platform}

On the left bank of dam site flood land and I, II accumulation terrace; On the right bank near normal storage level line flat terrain for I, II pedestal terrace. No gentle slope platform on the left bank of the lower dam site; The right level for the flood land and I accumulation terrace. The upper and lower dam sites are distributed with floodplain and accumulation terrace.

\subsubsection{The slope structure}

The upper dam site rocks steeply upstream, for a slightly symmetric width of the $\mathrm{V}$ - shaped transverse valley. The rock strata in the lower dam site steeply incline the left bank to the downstream, which is a v-shaped inclined valley with slightly symmetric width and width.

\subsubsection{Formation lithology}

The lithology of the upper dam site is mainly composed of medium - fine crystal dolomite, with a small amount of powder crystal dolomite, with single lithology and good uniformity. The lithology of the lower dam site is mainly powder-and-fine crystal dolomite, with a small amount of argillaceous fine crystal bearing argillaceous dolomite, argillaceous fine crystal carbonaceous shale, argillaceous slate and dolomitic sand mudstone. The lithology is complex and there is obvious heterogeneity. Therefore, the lithology of the upper dam site is single; The lithology of the lower dam site is relatively complex.

\subsubsection{Geological structure}

There are 3 regional II level structure, level 3 III structural plane, grade 12 IV structural plane, five groups V level structure, stable monoclinic structure area at the upper dam site. There are 3 regional II structural plane, 6 III structural plane, 13 IV structural plane, three groups of structural plane $\mathrm{V}$ level at the lower dam site. The downstream of the dam site is a small syncline, the dam site is located in a wing of syncline, is a stable monocline structure area. Comparatively speaking, the fault and fold structure of the lower dam site are more developed than that of the upper dam site.

\subsubsection{Type and depth of groundwater}

Underground water on the left bank of the upper dam site is $12 \mathrm{~m} \sim 51 \mathrm{~m}$ deep. The right bank is $5 \mathrm{~m} \sim 79 \mathrm{~m}$. Underground water in the left bank below the normal water level line is buried $8 \mathrm{~m} \sim 18 \mathrm{~m}$ deep. The right bank is $6 \mathrm{~m} \sim 22 \mathrm{~m}$. The buried depth of groundwater on the left bank of the lower dam site is $30 \mathrm{~m} \sim 83 \mathrm{~m}$; The right bank is $20 \mathrm{~m} \sim 78 \mathrm{~m}$. The buried depth of left bank groundwater below the normal water level line is $10 \mathrm{~m} \sim 24 \mathrm{~m}$; The right bank is $13 \mathrm{~m} \sim 23 \mathrm{~m}$. The underground water level at the lower dam site is relatively deep.

Based on the comprehensive analysis and comparison, the topographic conditions of the upper and lower dam sites are good, and the comparison of the stratigraphic lithology, geological structure, hydrogeological conditions and other factors indicates 
that the engineering geological conditions of the upper dam site are slightly better than those of the lower dam site.

\subsection{Comparison of kinetic energy indicators}

The lower dam site is increased by about $791 \times 10^{4} \mathrm{~m}^{3}$ than the upper dam site. The upper dam site has no adjustment ability, and the lower dam site can reach daily adjustment. The installed capacity of the lower dam site is increased by $40 \mathrm{MW}$, ensuring that the output is increased by $12.42 \mathrm{MW}$, the annual average generating capacity is increased by $2.881 \times 10^{8} \mathrm{kw} \cdot \mathrm{h}$, the annual utilization hours are increased by $179 \mathrm{~h}$, and the rated water head is increased by $2.5 \mathrm{~m}$. The lower dam site is obviously superior to the upper one.

\subsection{Comparison of submergence loss}

The upper and lower dam site schemes have little difference in submerged arable land, and the submerged population is the same.The adverse effects of land acquisition for power station construction can be reduced by practical treatment measures. The total flooded area of the reservoir is $5.14 \mathrm{~km}^{2}$, the flooded area affects 909 people, and the flooded area of various houses is $35868.4 \mathrm{~m}^{2}$. The total submerged area of the lower dam site is $6.06 \mathrm{~km}^{2}$, and the submerged area is $0.92 \mathrm{~km}^{2}$ more than that of the upper dam site. The submerged area of the reservoir affects the population and the submerged housing area as the upper dam site. The submerged loss of the lower dam site is slightly greater than that of the upper dam site. The static investment for land acquisition and compensation for resettlement of the upper dam site reached 486.57 million yuan, the lower dam site was 563.49 million yuan, an increase of 76.92 million yuan over the upper dam site, and the investment in land acquisition and compensation for resettlement of the migrants increased by nearly 16 percent. In a word, the lower dam site inundation loss and the corresponding reservoir inundation compensation investment are slightly larger than the upper dam site, but they account for a small proportion in the total project investment and do not constitute a constraint factor for the dam site selection.

\subsection{Project layout and quantity comparison}

Through the following aspects of the upper and lower dam site hub layout patterns representative of the comprehensive technical and economic comparison.

The terrain of the upper and lower dam sites is open, which are slightly symmetrical $\mathrm{v}$-shaped transverse valleys and oblique valleys respectively. The mountains on both sides are strong and the terrain is complete, and there is no development of mountain passes on either side, and there is no terrain condition for laying shore spillway. The upper and lower dam sites are suitable for the hub layout of gravity dam and riverbed type powerhouse, and the lower dam site topography is slightly better than the upper dam site.

The dam foundation rock mass at the upper dam site has simple structure, hard rock mass, shallow weathering, no obvious unloading, no large structural plane distribution in the building area, and good uniformity; Dam site under the dam foundation rock lithology is relatively complex, the local position of dam foundation rock mass has certain inhomogeneity, dam foundation level II within the framework of the development of structure in the face of dam foundation stability has certain adverse effect, but take treatment does not affect the foundation of the dam stability against sliding.

In terms of the layout of hydraulic engineering junctions, the upper dam site uses the left bank floodplain to arrange the workshop, the right bank riverbed to arrange the flood discharge buildings, the lower dam site uses the left bank main channel to arrange the workshop, and the right bank to arrange the flood discharge buildings. The layout of the upper dam site and the lower dam site has the characteristics of compact layout and good flood discharge energy dissipation conditions. The upper and lower dam sites on the left bank of the plant are technically feasible.

In terms of the main engineering quantities of the hub, the alluvial layer at the floodplain of the upper dam site is deep, the foundation surface of the dam body is low, the maximum dam height is $8 \mathrm{~m}$ higher than that of the lower dam site, and the engineering quantities of the hub such as excavation and concrete are relatively large. The alluvial layer at the lower dam site is shallow, the foundation plane is higher, and the dam height is correspondingly lower, but the rock mass unevenness and the unfavorable structural plane of the dam foundation cause the foundation treatment amount of the lower dam site to be larger than that of the upper dam site.

According to the project volume and preliminary economic analysis, the cost of the hydraulic hub project of the representative upper and lower dam sites is respectively 891.5213 million yuan, 874.9948 million yuan and 16.52 million yuan less than the upper dam site.

Therefore, the lower dam site is superior to the upper dam site from the comprehensive comparison of engineering layout and quantity.

\subsection{Comparison of mechanical, electrical and metal structures}

Shitouzhai Hydropower Station is a low-head dam-type development power station. The upper and lower dam sites have rated heads of $21 \mathrm{~m}$ and $23.5 \mathrm{~m}$, respectively. The installed capacity of the power station is $480 \mathrm{MW}$ and 520MW, respectively.

According to the layout of the upper and lower dam site plans and other main equipment, the main transformer, distribution unit and electrical secondary equipment in the upper and lower dam site plans are 
basically the same, so the investment and installation cost of electrical equipment are basically the same.

According to general layout of the program, metal structure equipment layout in the water table hole, flushing bottom hole, power plant water intake, buildings and tail water diversion structures, the upper and lower dam site of metal structure arrangement form basic same, but each solution metal structure equipment due to the orifice size of the program design of quantities are different with head. On the whole, the number of metal structure equipment at the upper and lower dam sites is the same, the size of access door, quick accident door and tail water access door in the upper dam site scheme is larger than that in the lower dam site scheme, and the total weight of equipment, corresponding equipment investment and installation cost are also larger. The total weights of the metal structure equipment in the upper and lower dam sites are $12547 \mathrm{t}$ and $12457 \mathrm{t}$ respectively.

The mechanical, electrical and metal structures of the upper and lower dam sites are basically the same, and both schemes are technically feasible. In contrast, the installed capacity of the upper dam site is small, the size of the units is large, and the weight of the units and the metal structure is large. According to the preliminary economic analysis, the cost of electromechanical and metal structure equipment and installation was 18.52 million yuan more than that of the lower dam site. The lower dam site is superior to the upper dam site in terms of electromechanical structure and metal structure.

\subsection{Comparison of construction conditions}

The upper and lower dam sites have the same diversion structure layout, diversion standard and diversion procedure, which all have the advantages of compact layout, low diversion project cost and short total construction period. There is little difference between the two schemes in terms of construction.

\subsection{Comparison of economic indicators}

The investment difference between the upper and lower dam sites of Shitouzhai Hydropower Station mainly consists of two parts: submerged compensation static investment and construction auxiliary project investment. According to the design results of the pre-feasibility stage, the total static investment of the lower dam site is increased by 385.32 million yuan compared with the upper dam site.

The comparative results of investment and economic indicators of the upper and lower dam sites of Shitou Village are shown in Table 1.

As can be seen from Table 1, the investment at the lower dam site has increased somewhat compared with that at the upper dam site, but the energy index has increased more, and the total cost is still the minimum, which has obvious economic advantages.
Table 1 Comparison table of project investment and financial and economic indicators of dam site comparison Scheme.

\begin{tabular}{|c|c|c|c|c|}
\hline $\begin{array}{c}\text { The } \\
\text { serial } \\
\text { number }\end{array}$ & project & unit & $\begin{array}{c}\text { Upper } \\
\text { dam site }\end{array}$ & $\begin{array}{c}\text { Lower } \\
\text { dam site }\end{array}$ \\
\hline 1 & $\begin{array}{c}\text { The installed } \\
\text { capacity }\end{array}$ & MW & 480 & 520 \\
\hline 2 & The total investment & $\begin{array}{c}\text { One hundred } \\
\text { million yuan }\end{array}$ & 46.903 & 51.367 \\
\hline 3 & $\begin{array}{c}\text { Dynamic unit } \\
\text { kilowatt investment }\end{array}$ & yuan/kW & 9771 & 9878 \\
\hline 4 & $\begin{array}{c}\text { Dynamic investment } \\
\text { per unit of electricity }\end{array}$ & yuan/kW.h & 1.99 & 2.02 \\
\hline 5 & $\begin{array}{c}\text { Financial internal } \\
\text { rate of return on } \\
\text { capital }\end{array}$ & $\%$ & 9.85 & 9.87 \\
\hline 6 & Payback period & years & 14.74 & 14.73 \\
\hline 7 & $\begin{array}{c}\text { Loan repayment } \\
\text { period }\end{array}$ & years & 21.23 & 21.24 \\
\hline 8 & $\begin{array}{c}\text { Total revenue from } \\
\text { electricity generation } \\
\text { sales }\end{array}$ & $\begin{array}{l}\text { One hundred } \\
\text { million yuan }\end{array}$ & 156.25 & 164.89 \\
\hline
\end{tabular}

\section{Conclusion}

According to the comprehensive technical and economic comparison, the lower dam site is superior to the upper dam site, the lower dam site is selected as the recommended dam site during the pre-feasibility study stage, and the practice of selecting the dam site during the pre-feasibility study stage of this power station can provide a reference for the pre-feasibility design of similar large and medium-sized power stations in the future.

\section{Acknowledgment}

Scientific Research Fund project of Yunnan Education Department in 2021(2021J0970)

\section{References}

1. Li, X.D. (2019) Selection of dam site and dam type for hydropower stations. Shaanxi province water conservancy, 8: 164-168.

2. Zhan, T.Y. (2020) Comparison and selection of dam site and dam type scheme for Kushanhe Reservoir. Shaanxi province water conservancy, 4: $150-152$.

3. Wang, X.M., Yang, Q.G. (2018) SL319-2018 Specification for design of concrete gravity DAMS. China Water Resources and Hydropower Press, BeiJin.

4. Zhou, J.P., Dang, L.C. (2011). Hydraulic Design Manual volume 5 Concrete Dam. China Water Resources and Hydropower Press, BeiJin. 